\title{
Enhanced glucose cycling and suppressed de novo synthesis of glucose-6-phosphate result in a net unchanged hepatic glucose output in ob/ob mice
}

\author{
R. H. J. Bandsma ${ }^{1}$ A. Grefhorst ${ }^{1}$ T. H. van Dijk ${ }^{1}$ F. H. van der Sluijs ${ }^{1}$ A. Hammer ${ }^{1}$ D.-J. Reijngoud ${ }^{1}$ \\ F. Kuipers ${ }^{1}$ \\ ${ }^{1}$ The Centre for Liver, Digestive and Metabolic Diseases, Research Laboratory of Paediatrics, University Hospital Groningen, \\ Groningen, The Netherlands
}

\begin{abstract} Aims/hypothesis. Leptin-deficient $o b / o b$ mice are hyperinsulinaemic and hyperglycaemic; however, the cause of hyperglycaemia remains largely unknown.

Methods. Glucose metabolism in vivo in 9-h fasted $o b / o b$ mice and lean littermates was studied by infusing $\left[\mathrm{U}-{ }^{13} \mathrm{C}\right]$-glucose, $\left[2-{ }^{13} \mathrm{C}\right]$-glycerol, $\left[1-{ }^{2} \mathrm{H}\right]$-galactose and paracetamol for $6 \mathrm{~h}$, applying mass isotopomer distribution analysis on blood glucose and urinary paracetamol-glucuronide.

Results. When expressed on the basis of body weight, endogenous glucose production (109 \pm 23 vs $152 \pm 27 \mu \mathrm{mol} \cdot \mathrm{kg}^{-1} \cdot \mathrm{min}^{-1}$, obese versus lean mice, $p<0.01)$ and de novo synthesis of glucose-6-phosphate $\left(122 \pm 13\right.$ vs $160 \pm 6 \mu \mathrm{mol} \cdot \mathrm{kg}^{-1} \cdot \mathrm{min}^{-1}$, obese versus lean mice, $p<0.001$ ) were lower in $o b / o b$ mice than in lean littermates. In contrast, glucose cycling was greatly increased in obese mice $\left(56 \pm 13\right.$ vs $26 \pm 4 \mu \mathrm{mol} \cdot \mathrm{kg}^{-1} \cdot \mathrm{min}^{-1}$, obese versus lean mice, $p<0.001$ ). As a result, total he-
\end{abstract}

patic glucose output remained unaffected $(165 \pm 31$ vs $178 \pm 28 \mu \mathrm{mol} \cdot \mathrm{kg}^{-1} \cdot \mathrm{min}^{-1}$, obese vs lean mice, NS). The metabolic clearance rate of glucose was significantly lower in obese mice $\left(8 \pm 2 \mathrm{vs} 18 \pm 2 \mathrm{ml} \cdot \mathrm{kg}^{-1} \cdot \mathrm{min}^{-1}\right.$, obese versus lean mice, $p<0.001)$. Hepatic mRNA levels of genes encoding for glucokinase and pyruvate kinase were markedly increased in $o b / o b$ mice.

Conclusions/interpretation. Unaffected total hepatic glucose output in the presence of hyperinsulinaemia reflects hepatic insulin resistance in ob/ob mice, which is associated with markedly increased rates of glucose cycling. Hyperglycaemia in $o b / o b$ mice primarily results from a decreased metabolic clearance rate of glucose.

Keywords Glucose-6-phosphate - Gluconeogenesis · Glycogen · Glycogenolysis · Hepatic glucose production - Mass isotopomer distribution analysis . ob/ob mice $\cdot$ Stable isotopes.

Received: 5 May 2004 / Accepted: 12 July 2004

Published online: 1 December 2004

CC Springer-Verlag 2004

D.-J. Reijngoud (

The Centre for Liver, Digestive and Metabolic Diseases,

Research Laboratory of Paediatrics, CMC IV/2,

University Hospital Groningen, P.O. Box 30.001,

9700 RB Groningen, The Netherlands

E-mail: d.j.reijngoud@med.rug.nl

Tel.: +31-50-3613295

Fax: +31-50-3611746

Abbreviations: G6P, glucose-6-phosphate - G6pase, glucose-6phosphatase - MIDA, mass isotopomer distribution analysis Par-GlcUA, paracetamol-glucuronic acid · Ppar $\gamma$, peroxisome proliferator-activated receptor gamma $\cdot$ Srebp-1c, sterol regulatory element-binding protein-1c

\section{Introduction}

Hyperinsulinaemia and fasting hyperglycaemia are hallmarks of type 2 diabetes. Insulin resistance of peripheral organs (muscle and adipocytes), as well as of the liver, may contribute to fasting hyperglycaemia. Peripheral insulin resistance reduces the ability of peripheral organs to clear glucose from the circulation. Hepatic insulin resistance develops in two stages. During the early stages in the development of type 2 diabetes, characterised by hyperinsulinaemia and normoglycaemia, hepatic glucose production is still normal under fasting conditions. However, during absorptive phases when insulin concentrations are elevated, hepatic glucose production remains inappropriately high. At later stages in the development of type 2 dia- 
betes in humans, hepatic glucose production starts to increase even under fasting conditions [1].

Both gluconeogenesis and glycogenolysis may contribute to elevated hepatic glucose production. Furthermore, data indicates that cycling of glucose, the process of sequential glucose uptake and subsequent phosphorylation by glucokinase and dephosphorylation by glucose-6-phosphatase, occurs at increased rates in humans with type 2 diabetes [2,3]. Little is known about the quantitative role of glucose cycling in the increased production of hepatic glucose in type 2 diabetes. Depending on the methodologies used for quantification of hepatic glucose fluxes, increased glucose cycling may affect the estimation of rates of gluconeogenesis and glycogenolysis.

Leptin-deficient $o b / o b$ mice suffer from severe obesity and diabetes due to leptin deficiency, and provide a model for type 2 diabetes. These mice exhibit age-dependent hyperglycaemia and hyperinsulinaemia. Quantitative data on the perturbations of glucose metabolism in these mice in vivo are scarce. In vitro studies on perfused isolated livers of $o b / o b$ mice have shown that glycogen turnover is increased [4]. In addition, glucose cycling rates have been shown to be greatly increased in hepatocytes isolated from 24-h fasted $o b / o b$ mice [5].

Novel methodologies using multiple stable isotopes in vivo now allow the determination of flux rates through the separate metabolic pathways involved in hepatic carbohydrate metabolism $[6,7,8]$. In the current study, we used these methods to evaluate the quantitative role of gluconeogenesis, glycogenolysis and glucose cycling in hyperglycaemia in modestly fasted $o b / o b$ mice.

\section{Materials and methods}

Animals. Female $o b / o b$ mice $(n=7)$ and lean littermates $(n=7)$, 8 weeks of age and on a C57B1/6 genetic background, were purchased from Harlan (Zeist, The Netherlands). The mice were housed in a temperature-controlled $\left(2{ }^{\circ} \mathrm{C}\right)$ room with a dark-light cycle of $12 \mathrm{~h}$ each. Experimental procedures were approved by the Ethics Committee for Animal Experiments of the State University Groningen. Mice were fitted with a permanent catheter in the right atrium via the right jugular vein, as described previously [9]. Mice were allowed to recover from surgery for at least 4 days.

Materials. The following isotopes were used: $\left[2-{ }^{13} \mathrm{C}\right]$-glycerol $\left(99 \%{ }^{13} \mathrm{C}\right.$ atom percent excess), $\left[1-{ }^{2} \mathrm{H}\right]$-galactose $\left(98 \%{ }^{2} \mathrm{H}\right.$ atom percent excess) (Isotec, Miamisburg, Ohio, USA), [U$\left.{ }^{13} \mathrm{C}\right]$-glucose $\left(99 \%{ }^{13} \mathrm{C}\right.$ atom percent excess) (Cambridge Isotope Laboratories, Andover, Mass., USA). All chemicals used were reagent pro analysis grade. Blood spots and urine were collected on Schleicher and Schuell No. 2992 filter paper (Schleicher and Schuells', Hertogenbosch, The Netherlands). Infusates were freshly prepared and sterilised by the Hospital Pharmacy at the day before the experiment.

Animal experiments. Experiments were performed in awake, chronically catheterised mice, essentially as described previ- ously [10]. Mice were fasted for $9 \mathrm{~h}$, after which they were placed in metabolic cages to allow frequent collection of blood spots and urine. Mice were infused with a sterile solution containing $\left[\mathrm{U}-{ }^{13} \mathrm{C}\right]$-glucose $(13.9 \mu \mathrm{mol} / \mathrm{ml}), \quad\left[2-{ }^{13} \mathrm{C}\right]$-glycerol $(160 \mu \mathrm{mol} / \mathrm{ml}),[1-2 \mathrm{H}]$-galactose $(33 \mu \mathrm{mol} / \mathrm{ml})$ and paracetamol $(1.0 \mathrm{mg} / \mathrm{ml})$ at a rate of $0.6 \mathrm{ml} / \mathrm{h}$. During the experiment, blood glucose was measured using EuroFlash test strips (LifeScan Benelux, Beerse, Belgium). Blood spots were collected on filter paper before the start of the infusion and hourly afterwards until $6 \mathrm{~h}$ after the start of the infusion. Blood spots were airdried and stored at room temperature until analysis. Timed urine samples were collected on filter paper strips at hourly intervals. Strips were air-dried and stored at room temperature until analysis. At the end of the experiment, animals were anaesthetised with isofurane, and a large blood sample was collected in heparin-containing tubes by heart puncture. The sample was centrifuged immediately and stored at $-20{ }^{\circ} \mathrm{C}$ until analysis. The liver was quickly excised, weighed and immediately frozen in liquid nitrogen.

Determination of metabolite concentrations. Plasma was isolated from blood by centrifugation, and liver tissue was homogenised. Commercially available kits were use to determine plasma levels of $\beta$-hydroxybutyrate, lactate (Roche Diagnostics, Mannheim, Germany) and NEFA (Wako Chemicals, Neuss, Germany). Plasma insulin levels were determined by RIA (RI-13K; Linco Research, St. Charles, Mo., USA). Total liver protein content was determined according to the method of Lowry et al. [11].

Hepatic glycogen was determined by sonication after extraction with $1 \mathrm{~mol} / \mathrm{l} \mathrm{KOH}$. The extract was incubated at $90{ }^{\circ} \mathrm{C}$ for $30 \mathrm{~min}$, cooled and then adjusted to $\mathrm{pH} 4.5$ by the addition of $3 \mathrm{~mol} / \mathrm{l}$ acetic acid. Precipitated protein was removed by centrifugation. Glycogen was converted to glucose by treating the samples with amyloglucosidase. A glucose assay was then performed at $\mathrm{pH} 7.4$ with $\mathrm{ATP}, \mathrm{NADP}^{+}$, hexokinase and G6P dehydrogenase.

Liver samples for the determination of G6P were treated by sonication in a $5 \%(\mathrm{w} / \mathrm{v}) \mathrm{HClO}_{4}$ solution. Precipitated protein was removed by rapid centrifugation at $20000 \mathrm{~g}$ for $1 \mathrm{~min}$ in a cold microcentrifuge, and the supernatant was neutralised to $\mathrm{pH} 7$ by the addition of small amounts of a solution containing $2 \mathrm{~mol} / \mathrm{l} \mathrm{KOH}$ and $0.3 \mathrm{~mol} / \mathrm{l} \mathrm{MOPS}$. Levels of G6P were determined fluorimetrically with $\mathrm{NADP}^{+}$and G6P dehydrogenase.

Hepatic mRNA levels. Total RNA was isolated from liver tissue using the Trizol method (Invitrogen, Paisley, UK). Using random primers, RNA was converted to cDNA with M-MulvRT (Roche Diagnostics) according to the manufacturer's protocol. The cDNA levels of the genes of interest were measured by RT-PCR using the ABI Prism 7700 Sequence Detection System (Applied Biosystems, Foster City, Calif., USA). An amount of cDNA equivalent to $20 \mathrm{ng}$ of total RNA was amplified using the qPCR core kit (Eurogentec, Seraing, Belgium) according to the manufacturer's protocol with the appropriate forward and reverse primers (Invitrogen) and a template-specific 3'-TAMRA, 5'-FAM-labelled Double Dye Oligonucleotide probe (Eurogentec). Calibration curves were run on serial dilutions of pooled cDNA solutions as used in the assay. The data were processed using the ABI Sequence Detector v.1.6.3 (Applied Biosystems). Quantified expression levels were within the linear part of the calibration curves. PCR results were normalised by $18 \mathrm{~S}-\mathrm{rRNA}$ levels. The sequences of the primers and probes used in this study are listed in Table 1.

Mass isotopomer distribution analysis. Glucose and paracetamolglucuronic acid (Par-GlcUA) were extracted from blood spot and 
Table 1. Sequences of the primers and probes used in PCR measurements

\begin{tabular}{|c|c|c|c|}
\hline Gene & Sense & Sequence & GeneBank no./ref. \\
\hline$\beta$-actin & $\begin{array}{l}\text { forward } \\
\text { reverse } \\
\text { probe }\end{array}$ & $\begin{array}{l}\text { ACC CAC ACT GTG CCC ATC TAC } \\
\text { GCT CGG TCA GGA TCT TCA TGA } \\
\text { AGG GCT ATG CTC TCC CTC ACG CCA }\end{array}$ & NM_007393 \\
\hline 18S-rRNA & $\begin{array}{l}\text { forward } \\
\text { reverse } \\
\text { probe }\end{array}$ & $\begin{array}{l}\text { CGG CTA CCA CAT CCA AGG A } \\
\text { CCA ATT ACA GGG CCT CGA AA } \\
\text { CGC GCA AAT TAC CCA CTC CCG A }\end{array}$ & X00686 \\
\hline G6P translocase & $\begin{array}{l}\text { forward } \\
\text { reverse } \\
\text { probe }\end{array}$ & $\begin{array}{l}\text { GAG GCC TTG TAG GAA GCA TTG } \\
\text { CCA TCC CAG CCA TCA TGA GTA } \\
\text { CTC TGT ATG GGA ACC CTC GCC ACG }\end{array}$ & NM_008063 \\
\hline Glycogen synthase & $\begin{array}{l}\text { forward } \\
\text { reverse } \\
\text { probe }\end{array}$ & $\begin{array}{l}\text { GCT CTC CAG ACG ATT CTT GCA } \\
\text { GTG CGG TTC CTC TGA ATG ATC } \\
\text { CCT CTA CGG GTT TTG TAA ACA GTC ACG CC }\end{array}$ & NM_145572 \\
\hline Pyruvate kinase & $\begin{array}{l}\text { forward } \\
\text { reverse } \\
\text { probe }\end{array}$ & $\begin{array}{l}\text { CGT TTG TGC CAC ACA GAT GCT } \\
\text { CAT TGG CCA CAT CGC TTG TCT } \\
\text { AGC ATG ATC ACT AAG GCT CGA CCA ACT CGG }\end{array}$ & NM_013631 \\
\hline $\begin{array}{l}\text { Phosphoenolpyruvate } \\
\text { carboxykinase }\end{array}$ & $\begin{array}{l}\text { forward } \\
\text { reverse } \\
\text { probe }\end{array}$ & $\begin{array}{l}\text { GTG TCA TCC GCA AGC TGA AG } \\
\text { CTT TCG ATC CTG GCC ACA TC } \\
\text { CAA CTG TTG GCT GGC TCT CAC TGA CCC }\end{array}$ & NM_011044 \\
\hline
\end{tabular}

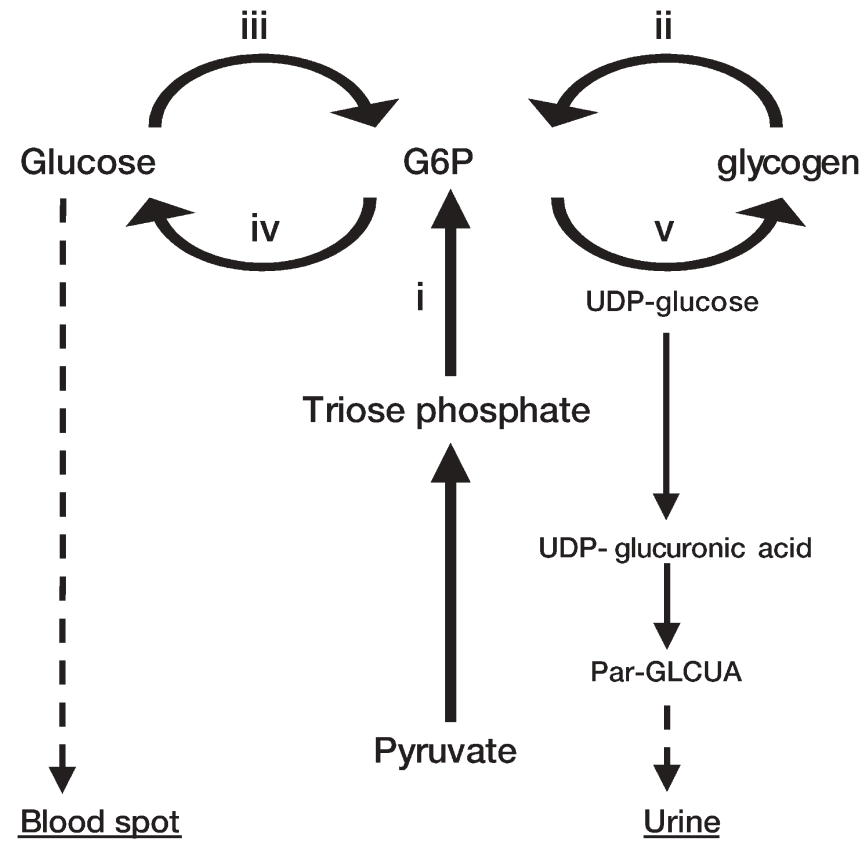

Fig. 1. Schematic model of calculated hepatic carbohydrate fluxes. The major metabolic pathways and enzymatic reactions involved in hepatic carbohydrate metabolism that share G6P as a metabolite are shown, apart from glycolysis, which cannot be assessed in this model. These pathways are as follows: (i) de novo synthesis of G6P; (ii) glycogenolysis; (iii) glucokinase; (iv) glucose-6-phosphatase; and (v) glycogen synthesis. Gluconeogenesis is represented by (i) and (iv) urine filter paper strips respectively, derivatised, and measured by GC-MS, essentially as described previously $[8,10]$. The fractional isotopomer distribution according to GC-MS $\left(\mathrm{m}_{0}-\mathrm{m}_{6}\right)$ was corrected for the fractional distribution due to the natural abundance of ${ }^{13} \mathrm{C}$ by multiple linear regression, as described by Lee et al. [6] to obtain the excess mole fraction of mass isotopomers $\mathrm{M}_{0}-\mathrm{M}_{6}$ due to incorporation of infused labelled compounds, i.e. $\left[2-{ }^{13} \mathrm{C}\right]$-glycerol, [U-13 C]-glucose and $[1-2 \mathrm{H}]$-galactose.

Figure 1 shows a graphical representation of the isotopic model applied in which the following metabolic pathways are considered: (i) de novo synthesis of G6P; (ii) glycogenolysis; (iii) glucokinase; (iv) glucose-6-phosphatase; and (v) glycogen synthesis. Gluconeogenesis is represented by the combination of the pathways (i) and (iv). Glycolysis is not considered in this model. Paracetamol, $\left[2-{ }^{13} \mathrm{C}\right]$-glycerol, $\left[\mathrm{U}-{ }^{13} \mathrm{C}\right]$-glucose and $[1-2 \mathrm{H}]$-galactose were used to calculate flux rates through the pathways mentioned above. Paracetamol, as its glycoconjugate Par-GlcUA, was used to sample UDP-glucose. Incorporation of [2-13 C]-glycerol into blood glucose and urinary Par-GlcUA was used to estimated the fractional contributions of de novo synthesis of G6P to blood glucose and UDP-glucose (via Par-GlcUA) respectively. These fractional contributions were subsequently converted into absolute rates of gluconeogenic flux into each of the compounds by multiplying by the rate of appearance of blood glucose and UDP-glucose (via Par-GlcUA) respectively. The rates of appearance of blood glucose and UDP-glucose were calculated from the isotopic dilution of $\left[\mathrm{U}-{ }^{13} \mathrm{C}\right]$-glucose and $\left[1-{ }^{2} \mathrm{H}\right]$-galactose in blood glucose and urinary Par-GlcUA respectively.

The whole-body blood glucose production rate $[\mathrm{Ra}$ (glc; whole body)], equal to blood glucose disposal $[\mathrm{Rd}(\mathrm{glc})]$ at isotopic steady-state, was calculated according to: 


$$
\begin{aligned}
R a(\text { glc } ; \text { wholebody })=R d(g l c)= & M_{6}(g l c)_{\text {infuse }} \\
& M_{6}(\text { glc })_{\text {blood }} \\
& \times \text { infusion }\left(\text { glc } ; M_{6}\right)
\end{aligned}
$$

in which $\mathrm{M}_{6}(\mathrm{glc})_{\text {infuse }}$ is the excess mole fraction of infused [U$\left.{ }^{13} \mathrm{C}\right]$-glucose, $\mathrm{M}_{6}(\mathrm{glc})_{\text {blood }}$ is the excess mole fraction of blood $\left[\mathrm{U}-{ }^{13} \mathrm{C}\right]$-glucose, and infusion $\left(\mathrm{glc} ; \mathrm{M}_{6}\right)$ is the infusion rate of uniformly labelled [U-13 C]-glucose.

Metabolic clearance rate of blood glucose $[\mathrm{MCR}(\mathrm{glc})]$ was calculated according to:

$\operatorname{MCR}(g l c)=R d(g l c) /[g l c]$

where $[\mathrm{glc}]$ is the blood glucose concentration in $\mathrm{mmol} / \mathrm{l}$.

The rates of endogenous glucose production [Ra(glc;endo)] were calculated according to:

$$
\begin{aligned}
R a(\text { glc } ; \text { endo })= & R a(\text { glc } ; \text { whole body }) \\
& - \text { infusion }\left(\text { glc } ; M_{6}\right)
\end{aligned}
$$

The rates of whole-body production of UDP-glucose [Ra(UDPglc; whole body)] were calculated according to:

$$
\begin{aligned}
\operatorname{Ra}(U D P g l c ; \text { whole body })= & M_{1}(\text { gal })_{\text {infuse }} / \\
& M_{1}(\text { Par }- \text { GlcUA }) \\
& \times \text { infusion }\left(\text { gal } ; M_{1}\right)
\end{aligned}
$$

in which $\mathrm{M}_{1}(\mathrm{gal})_{\text {infuse }}$ is the excess mole fraction of infused [1$\left.{ }^{2} \mathrm{H}\right]$-galactose, $\mathrm{M}_{1}$ (Par-GlcUA) is the excess mole fraction of urinary Par-[1-2 H]-GlcUA, and infusion $\left(\mathrm{gal} ; \mathrm{M}_{1}\right)$ is the infusion rate of $\left[1-{ }^{2} \mathrm{H}\right]$-galactose. Ra(UDPglc; whole body) was calculated assuming a constant and complete entry of infused galactose into the hepatic UDP-glucose pool. Furthermore, it was assumed that the fractional isotopomer distribution observed for Par-GlcUA reflects the fractional isotopomer distribution for UDP-glucose.

The rate of appearance of endogenously produced UDPglucose [Ra(UDPglc;endo)] was calculated according to:

$$
\begin{aligned}
\operatorname{Ra}(U D P g l c ; \text { endo })= & \operatorname{Ra}(U \text { UPglc; whole body }) \\
& -\operatorname{infusion}\left(\text { gal } ; M_{1}\right)
\end{aligned}
$$

In the isotopic model applied, stable isotopically labelled compounds, i.e. $\left[1-{ }^{2} \mathrm{H}\right]$-galactose and $\left[\mathrm{U}^{13} \mathrm{C}\right]$-glucose, were used that did not lose their labelled atom(s) upon entering metabolism. As a consequence, these compounds can re-enter the circulation (recycling), acting as an additional infusion of labelled compounds of unknown magnitude, which add to the excess mole fractions observed. This results in an underestimation of the rates of appearance of these compounds [12]. The contribution of recycling should therefore be added to the calculated rates of appearance of endogenous compounds to obtain the total rates of appearance of these compounds [12]. To calculate the recycling of $\left[\mathrm{U}_{-}{ }^{13} \mathrm{C}\right]$-glucose and $\left[1-{ }^{2} \mathrm{H}\right]$-galactose, two exchange factors are introduced: the fractional contribution of blood glucose to UDP-glucose formation [c(glc)], and the fractional contribution of UDP-glucose to blood glucose [c(UDPglc)]. These two factors are calculated according to:

$c(g l c)=M_{6}(P a r-G l c U A) / M_{6}(g l c)_{b l o o d}$

in which $\mathrm{M}_{6}$ (Par-GlcUA) is the excess mole fraction of urinary Par-[U-13C]-GlcUA; and

$c(U D P g l c)=M_{1}(g l c)_{b l o o d} / M_{1}($ Par - GlcUA $)$ in which $\mathrm{M}_{1}(\mathrm{glc})_{\text {blood }}$ is the excess mole fraction of blood [1$\left.{ }^{2} \mathrm{H}\right]$-glucose. The associated rates of recycling of blood glucose $[\mathrm{R}(\mathrm{r}(\mathrm{glc}))]$ and of UDP-glucose $[\mathrm{R}(\mathrm{r}(\mathrm{UDPglc}))]$ were calculated as follows:

$$
\begin{aligned}
& R(r(g l c))=(c(g l c) /(1-c(g l c))) \times R a(\text { glc; endo }) \\
& R(r(U D P g l c))=(c(U D P g l c) / \\
& (1-c(U D P g l c))) \\
& \times R a(U D P g l c ; \text { endo })
\end{aligned}
$$

Total rates of endogenous glucose production [totalRa(glc;endo)] and endogenous UDP-glucose [totalRa(UDPglc;endo)] are calculated according to:

$$
\begin{aligned}
& \operatorname{totalRa}(\text { glc } ; \text { endo })=R a(g l c ; \text { endo })+R(r(g l c)) \\
& \text { totalRa }(U D P g l c ; \text { endo })=R a(U D P g l c ; \text { endo }) \\
& +R(r(U D P g l c))
\end{aligned}
$$

The fractional contribution of the de novo synthesis of G6P to the production of glucose $[\mathrm{f}(\mathrm{glc})]$ and UDP-glucose [f(UDPglc)] was calculated from the incorporation of [2-13C]glycerol into glucose and Par-GlcUA respectively, as described in detail elsewhere $[7,8]$. The rates of the gluconeogenic fluxes into blood glucose [GNG(glc)] and into UDP-glucose [GNG(UDPglc)] were calculated according to:

$$
\begin{aligned}
G N G(g l c)= & f(\text { glc }) \times(\text { totalRa }(\text { glc } ; \text { endo }) \\
& \left.+ \text { infusion }\left(\text { glc } ; M_{6}\right)\right)
\end{aligned}
$$

and

$$
\begin{aligned}
G N G(U D P g l c)= & f(\text { UDPglc }) \\
& \times(\text { totalRa }(\text { UDPglc } ; \text { endo }) \\
& \left.+ \text { infusion }\left(\text { gal } ; M_{1}\right)\right)
\end{aligned}
$$

The de novo synthesis of G6P [GNG(G6P)] is the sum of GNG(glc) and GNG(UDPglc), corrected for the exchange of label between blood glucose and UDP-glucose, calculated according to:

$$
\begin{aligned}
G N G(G 6 P)= & G N G(g l c) \times(1-c(U D P g l c)) \\
& +G N G(U D P g l c) \times(1-c(g l c))
\end{aligned}
$$

The contribution of glycogenolysis to blood glucose formation [GLY(glc)] and UDP-glucose formation [GLY(UDPglc)] was calculated according to:

$G L Y(g l c)=$ total Ra $(g l c ;$ endo $)-G N G(g l c)$

in which the contribution of glycogenolysis to the total rate of appearance of glucose in blood is equal to the part that is not derived from gluconeogenesis; and

$$
\begin{aligned}
G L Y(U D P g l c)= & \text { total Ra }(\text { UDPglc;endo }) \\
& -G N G(U D P g l c) \\
& -g l c(U D P g l c),
\end{aligned}
$$

in which glc(UDPglc) represents the contribution of blood glucose to UDP-glucose, which was calculated according to:

$$
\begin{aligned}
g l c(U D P g l c)= & c(g l c) \times(\text { total Ra }(U D P g l c ; \text { endo }) \\
& \left.+ \text { infusion }\left(g a l ; M_{1}\right)\right)
\end{aligned}
$$

In contrast to blood glucose, the total rate of appearance of UDP-glucose is determined by: (i) gluconeogenic flux from 


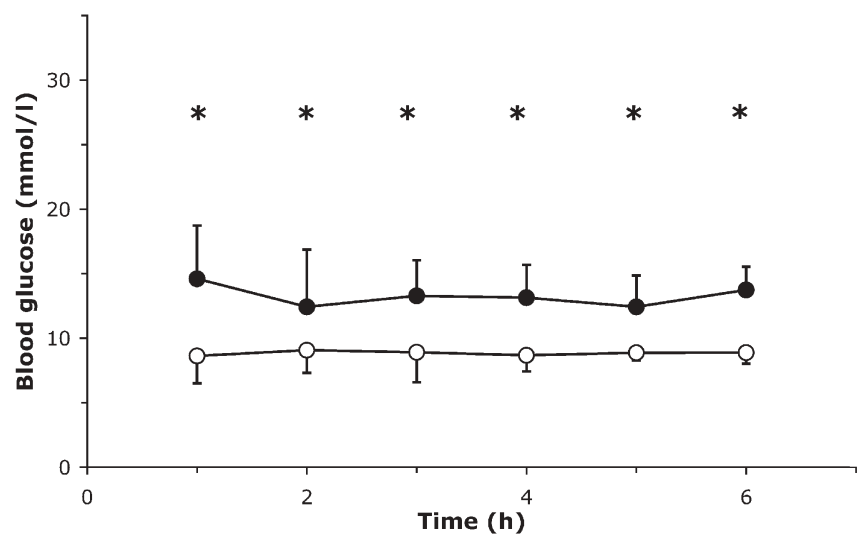

Fig. 2. Plasma glucose concentrations during infusion experiments in lean (empty circles, $n=7$ ) and $o b / o b$ (filled circles, $n=7)$ mice. Values shown are the means \pm SD. $* p<0.05$ vs lean animals

Table 2. Hepatic and plasma parameters in $o b / o b$ mice and lean littermates

\begin{tabular}{|c|c|c|}
\hline & $\begin{array}{l}\text { Lean mice } \\
(n=7)\end{array}$ & $\begin{array}{l}\text { ob/ob mice } \\
(n=7)\end{array}$ \\
\hline \multicolumn{3}{|l|}{ Liver } \\
\hline Body weight (g) & $22.7 \pm 1.2$ & $49.7 \pm 3.0^{\mathrm{a}}$ \\
\hline Liver weight (g) & $1.1 \pm 0.0$ & $2.6 \pm 0.4^{\mathrm{a}}$ \\
\hline $\begin{array}{l}\text { Relative liver weight } \\
\text { (\% body weight) }\end{array}$ & $4.7 \pm 0.3$ & $5.0 \pm 0.8$ \\
\hline Total liver protein (mg) & $156 \pm 20$ & $325 \pm 63^{a}$ \\
\hline $\begin{array}{l}\text { Liver protein content } \\
\text { (mg protein/g liver weight) }\end{array}$ & $144 \pm 18$ & $127 \pm 18$ \\
\hline G6P (nmol/g liver weight) & $118 \pm 56$ & $153 \pm 34$ \\
\hline $\begin{array}{l}\text { Glycogen ( } \mu \text { mol } \\
\text { glucose/g liver weight) }\end{array}$ & $179 \pm 16$ & $207 \pm 11^{\mathrm{a}}$ \\
\hline \multicolumn{3}{|l|}{ Plasma } \\
\hline Glucose (mmol/l) & $8.8 \pm 0.5$ & $13.2 \pm 1.9^{a}$ \\
\hline Insulin (pmol/l) & $45 \pm 10$ & $900 \pm 480^{\mathrm{a}}$ \\
\hline NEFA $(\mathrm{mmol} / \mathrm{l})$ & $0.5 \pm 0.1$ & $0.9 \pm 0.2^{\mathrm{a}}$ \\
\hline$\beta$-Hydroxybutyrate (mmol/l) & $0.8 \pm 0.4$ & $3.1 \pm 1.4^{\mathrm{a}}$ \\
\hline Alanine $(\mu \mathrm{mol} / \mathrm{l})$ & $133 \pm 113$ & $176 \pm 33$ \\
\hline Lactate $(\mathrm{mmol} / \mathrm{l})$ & $3.5 \pm 1.0$ & $3.5 \pm 1.0$ \\
\hline
\end{tabular}

a $p<0.05$ vs lean animals

G6P; (ii) glycogenolysis; and (iii) the flux of blood glucose into the UDP-glucose pool. The flux of glycogen into UDPglucose is a measure of glycogen / glucose-1-phosphate cycling [8].

The individual isotopic fluxes through the various enzymes involved in hepatic glucose metabolism were calculated based on a factorial model by adding the different contributions to the flux rates. For the enzymes glucokinase (Gk), glucose-6phosphatase (G6pase), glycogen synthase (Gs) and glycogen phosphorylase (Gp) the flux rates were calculated according to:

$G k=g l c(U D P g l c)+R(r(g l c))$

in which only two contributions to the flux through Gk are considered (i.e. the flux of blood glucose into UDP-glucose
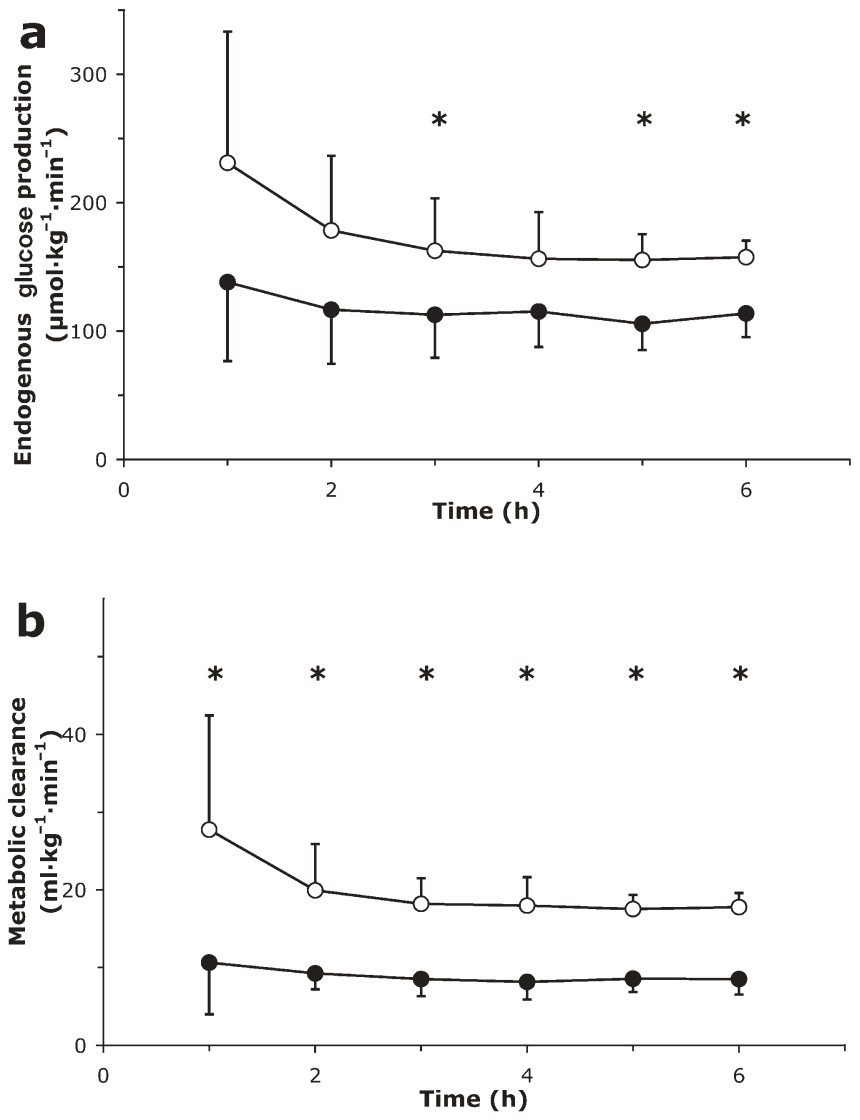

Fig. 3. Endogenous glucose production (a) and metabolic clearance (b) during the infusion experiments in lean (empty circles, $n=7$ ) and $o b / o b$ (filled circles, $n=7$ ) mice. Values shown are the means $\pm \mathrm{SD}$. $* p<0.05$ vs lean animals

and glucose / G6P cycling), whereas glycolysis is not included

$$
\begin{aligned}
& \begin{array}{r}
\text { G6 pase }=\text { total Ra }(\text { glc } ; \text { endo }) \\
=G N G(g l c)+G L Y(g l c)
\end{array} \\
& \text { and }=\text { Ra }(\text { UDPglc } ; \text { wholebody }) \\
& G p=G L Y(g l c)+G L Y(U D P g l c)
\end{aligned}
$$

in which two contributions to the flux through glycogen phosphorylase are considered (i.e. glycogenolysis resulting in blood glucose appearance and glycogen/G1P cycling).

Statistical analysis. All values are means \pm SD. Levels of significance of difference of metabolite concentrations, gene expression and the values of the individual time points during isotope infusion experiments were determined using the nonparametric Mann-Whitney test for unpaired data. Levels of significance of differences between the averages of the values of the fluxes at individual time points between 3 and $6 \mathrm{~h}$ during the experiment were estimated using repeated measures ANOVA. A $p$ value of less than 0.05 was considered statistically significant. 

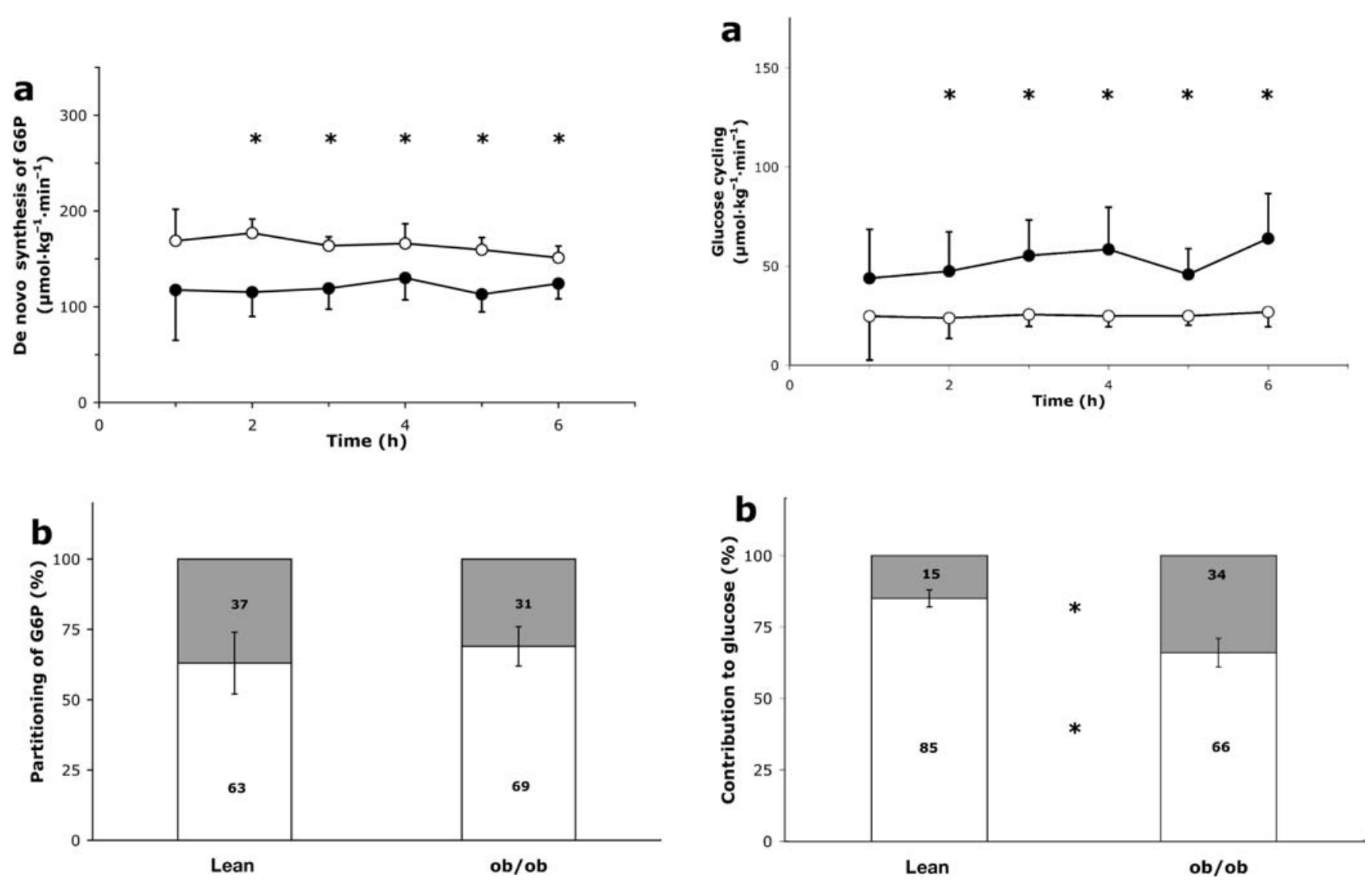

Fig. 4 a. The rate of de novo synthesis of G6P in lean (empty circles) and $o b / o b$ (filled circles) mice. b. The partitioning of the rates of de novo synthesis of G6P to UDP-glucose (shaded area) and to glucose (white area) during the last $3 \mathrm{~h}$ of the infusion experiment in lean and $o b / o b$ mice. Values shown are the means $\pm \mathrm{SD}$ ( $n=7$ for each group). ${ }^{*} p<0.05$ vs lean animals

\section{Results}

Body and liver weights of obese mice were more than double those of lean mice (Table 2). Consequently, normalisation of liver weight to body weight yielded no difference between obese and lean mice. Protein contents per gram of liver tissue were not significantly different between obese and lean mice. Hepatic glycogen content was mildly elevated in ob/ob mice, whereas G6P levels were not significantly different between the two groups. At the end of the experiment, plasma NEFA concentrations were almost two-fold higher in the $o b / o b$ mice than in the lean mice. Plasma lactate and alanine concentrations were similar in the two groups, whereas plasma $\beta$ hydroxybutyrate concentrations were elevated in $o b / o b$ mice.

Figure 2 shows the blood glucose concentrations of the two groups of mice during the infusion experiment. Obese mice were clearly hyperglycaemic $(8.8 \pm 0.5$ vs $13.2 \pm 1.9 \mathrm{mmol} / \mathrm{l}$, lean versus obese mice, $p<0.05)$ and

Fig. 5 a. Rate of cycling between glucose and G6P during the infusion experiment in lean (empty circles) and $o b / o b$ (filled circles) mice. b. The contributions of endogenous glucose production (white area) and glucose cycling (shaded area) to the total endogenous glucose production in lean and $o b / o b$ mice during the last $3 \mathrm{~h}$ of the infusion experiment. Values shown are the means $\pm \mathrm{SD}$ ( $n=7$ for each group). $* p<0.05$ vs lean animals

hyperinsulinaemic. Insulin concentrations remained constant $(45 \pm 10 \mathrm{pmol} / \mathrm{l}$ at $t=0$ and $60 \pm 45 \mathrm{pmol} / \mathrm{l}$ at $t=6$ h) during the experiment in lean mice, but decreased from $900 \pm 480 \mathrm{pmol} / 1$ at $t=0$ to $435 \pm 270 \mathrm{pmol} / 1$ at $t=6 \mathrm{~h}$ in $o b / o b$ mice.

Figure 3 shows endogenous glucose production [Ra(glc;endo), equation (3)] and the metabolic clearance rate of glucose [MCR(glc), equation (2)]. At isotopic steady-state, i.e. between $3 \mathrm{~h}$ and $6 \mathrm{~h}$ after the start of the infusion of labelled compounds, endogenous glucose production was significantly decreased in $\mathrm{ob} / \mathrm{ob}$ mice $\left(152 \pm 27\right.$ vs $109 \pm 23 \mu \mathrm{mol} \cdot \mathrm{kg}^{-1} \cdot \mathrm{min}^{-1}$, lean versus obese mice, $p<0.001$ ), as was the metabolic clearance rate of glucose $\left(18 \pm 2\right.$ vs $8 \pm 2 \mathrm{ml} \cdot \mathrm{kg}^{-1}$. $\min ^{-1}$, lean versus obese mice, $\left.p<0.001\right)$.

The rate of de novo synthesis of G6P [GNG(G6P), equation (14)] in obese mice was significantly lower than that in lean control mice $(160 \pm 6 \mathrm{vs} 122 \pm 13 \mu \mathrm{mol}$. $\mathrm{kg}^{-1} \cdot \mathrm{min}^{-1}$, lean versus obese mice, $\left.p<0.001\right)$ (Fig. 4a). In obese mice, the partitioning of newly synthesised G6P towards plasma glucose or glycogen was 

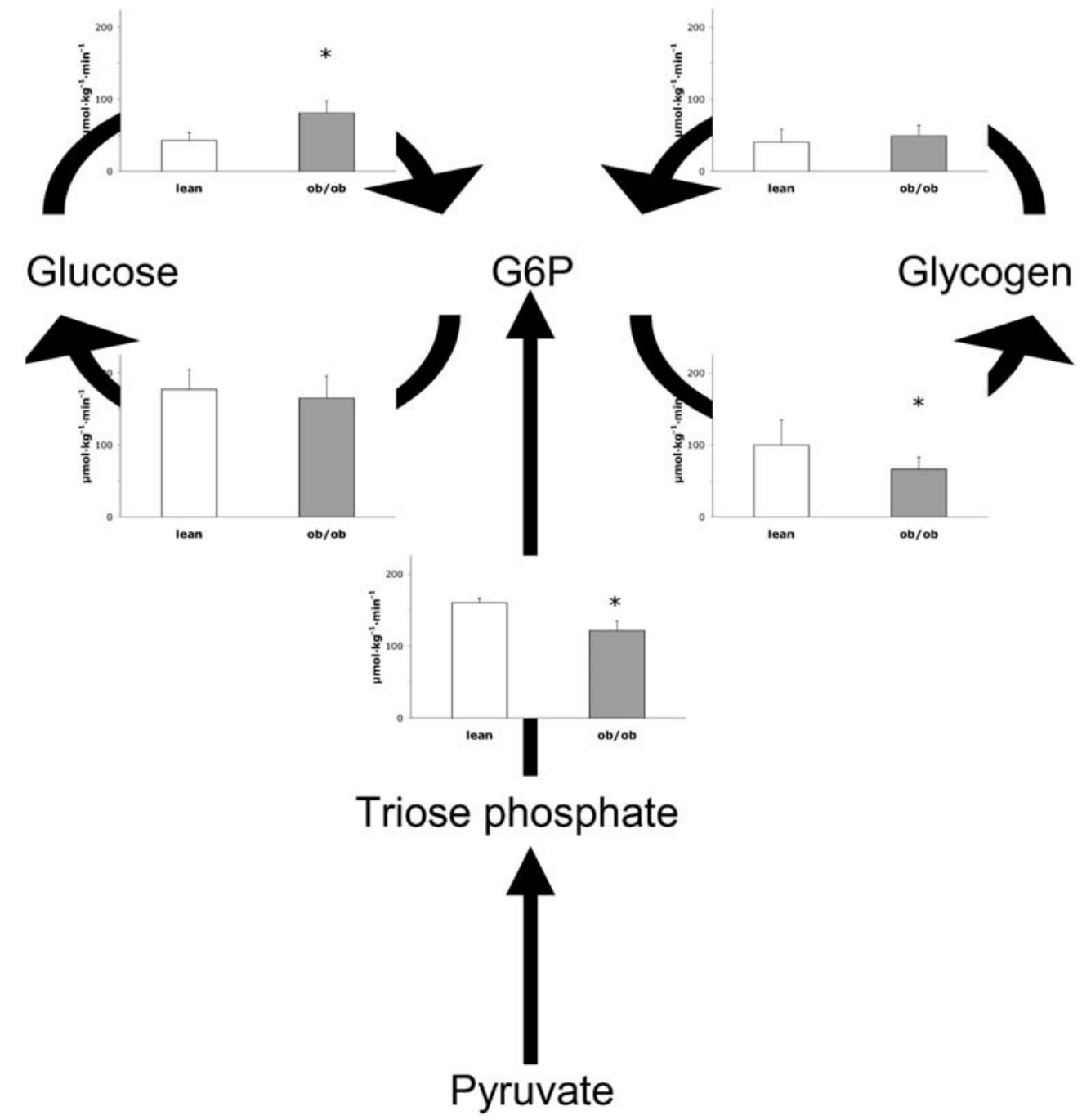

Fig. 6. Separate fluxes through the relevant metabolic pathways involved in hepatic carbohydrate metabolism during the last $3 \mathrm{~h}$ of the infusion experiment in lean and $o b / o b$ mice. Values shown are the means $\pm \mathrm{SD}$ ( $n=7$ for each group). * $p<0.05$ vs lean animals

similar to that in lean control mice (Fig. 4b). In contrast, glucose cycling $[\mathrm{R}(\mathrm{r}(\mathrm{glc}))$, equation (8)] was greatly enhanced in obese mice $(56 \pm 13 \mu \mathrm{mol}$. $\mathrm{kg}^{-1} \cdot \mathrm{min}^{-1}$ vs $26 \pm 4 \mu \mathrm{mol} \cdot \mathrm{kg}^{-1} \cdot \mathrm{min}^{-1}$, obese versus lean mice, $p<0.001$ ) (Fig. 5a). Consequently, total endogenous glucose production, i.e. the sum of endogenous glucose production and glucose cycling, was not significantly different in obese and lean mice $(178 \pm 28$ vs $165 \pm 31 \mu \mathrm{mol} \cdot \mathrm{kg}^{-1} \cdot \mathrm{min}^{-1}$, lean versus obese mice, NS) (Fig. 5b).

Figure 6 shows the calculated mean values obtained at steady-state for the individual fluxes through the various pathways of hepatic glucose metabolism. As anticipated, the calculated isotopic flux through glucokinase [Gk, equation (18)] was strongly increased in obese mice. The glucose-6-phosphatase flux [G6pase, equation (19)], equivalent to the total endogenous glucose production, was unchanged. The flux through glycogen phosphorylase [Gp, equation (21)] was not altered significantly, whereas the glycogen synthase flux [Gs, equation (20)] was significantly decreased in obese mice compared with lean littermates.

Table 3 provides a summary of the calculated flux rates, normalised to either body weight or amount of liver protein (liver is the major glucose-producing organ). Independent of the method of normalisation, the same conclusions can be drawn with respect to the changes in glucose metabolism in lean and $o b / o b$ mice.

Levels of expression of relevant genes in the liver of lean and $o b / o b$ mice are shown in Figure 7. The expression of the genes encoding glucokinase and livertype pyruvate kinase were strongly up-regulated in the liver of $o b / o b$ mice. The mRNA levels of other key enzymes involved in carbohydrate metabolism (i.e. phosphoenolpyruvate carboxykinase, G6P hydrolase and G6P translocase) did not differ significantly between obese and lean mice. It has previously been shown that the expression of the genes encoding sterol regulatory element-binding protein-1c (Srebp-1c) and peroxisome proliferator-activated receptor- $\gamma$ (Ppar $\gamma)$, 
Table 3. Summary of the calculated values of the various flux rates, using the isotopic model shown in Fig. 1, normalised to either body weight or liver protein

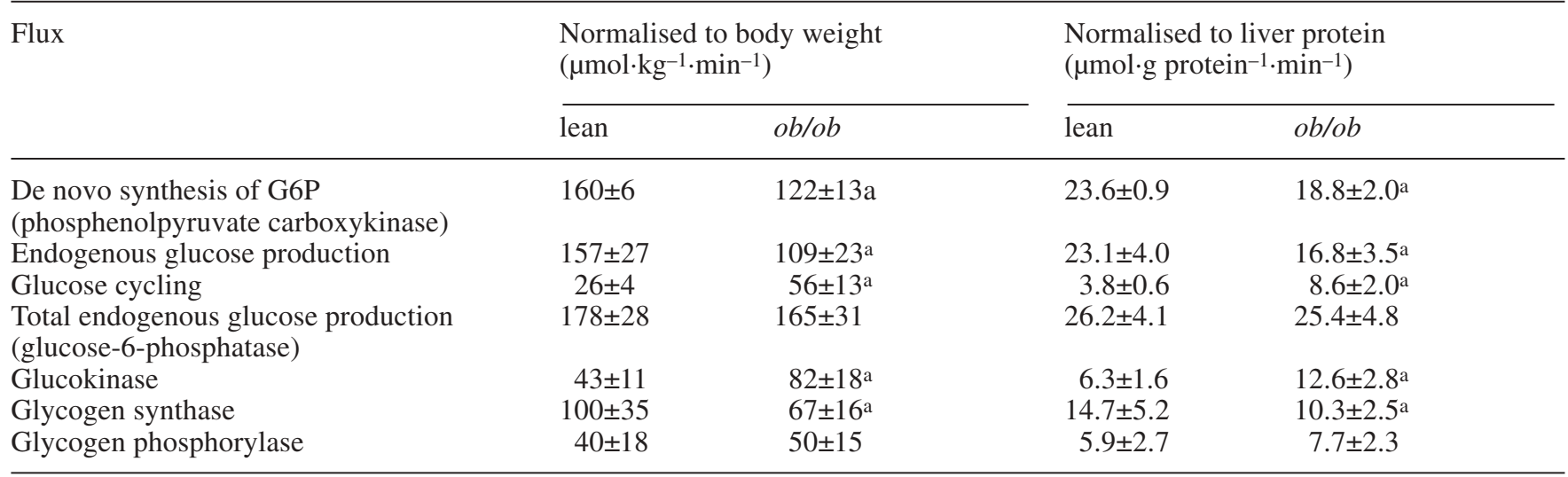

a $p<0.05$ vs lean animals

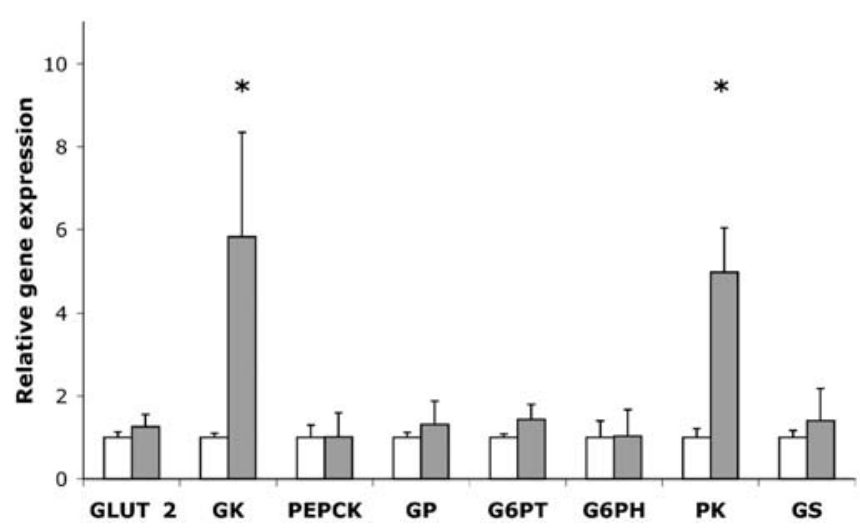

Fig. 7. Gene expression of enzymes involved in glucose metabolism at the end of the infusion experiment in lean $(n=3)$ and $o b / o b(n=3)$ mice. Levels of cDNA were measured by RTPCR as described in the Materials and methods section. Data are expressed relative to 18S-rRNA and the results of the lean animals are set equal to 1 . Expression of genes was normalised to $18 \mathrm{~S}$-rRNA, since the level of $\beta$-actin mRNA in livers of obese mice was increased by $\sim 30 \%$ when normalised by liver weight. In contrast, 18S-rRNA levels were similar in livers of obese and lean mice. * $p<0.05$ vs lean animals. G6ph, G6P hydrolase; G6pt, G6P translocase; Gk, glucokinase; Gp, glycogen phosphorylase; Gs, glycogen synthase; Pepck, phosphoenolpyruvate carboxykinase; $\mathrm{Pk}$, pyruvate kinase

transcription factors involved in control of hepatic glucose and fat metabolism, is significantly elevated in the liver of $o b / o b$ mice compared with that of their lean littermates [13]. Furthermore, mRNA levels of Irs-1, but particularly Irs-2, were observed to be strongly repressed in the liver of obese mice [13].

\section{Discussion}

The leptin-deficient $o b / o b$ mouse is a commonly used mouse model of type 2 diabetes, but quantitative in vivo data on the disturbances that underlie hypergly- caemia in this model are sparse. In this study, we determined flux rates through various pathways relevant in hepatic carbohydrate metabolism in lean and $o b / o b$ mice. When expressed per unit of body weight or liver protein, hepatic glucose metabolism activity was, in general, suppressed in obese mice compared with that in their lean littermates. However, glucose cycling was an exception to this, and was observed to be greatly increased in obese mice. Interestingly, the newly produced G6P was not preferentially directed towards plasma glucose in $o b / o b$ mice, but instead was partitioned to glycogen stores to a similar extent as that observed in lean mice. Furthermore, the expression of genes of key enzymes involved in glucose metabolism were similar in livers of $o b / o b$ and lean mice, apart from the expression of glucokinase and liver-type pyruvate kinase which was increased in the liver of $o b / o b$ mice.

Before discussing the results, some methodological issues have to be addressed. In this study, a multiple isotope infusion protocol was used to calculate the relevant fluxes of glucose metabolism [7]. The validity of the isotope model, with the application of glycoconjugates, and the mass isotopomer distribution analysis (MIDA) approach has been substantiated in various studies, although some controversy still remains $[14,15]$. Since the contribution of glycolysis to intracellular G6P metabolism has not been included in this model, the calculated flux rate through glucokinase represents a minimal estimate. We have validated the application of MIDA in 9-h fasted C57Bl/6 mice in a separate study [10]. In $24-\mathrm{h}$ fasted mice, no stable isotopic steady-state could be obtained [10]. In the current study, we compared hepatic glucose metabolism in groups of mice with strongly different body compositions. Our data show that, with respect to hepatic glucose metabolism, normalisation to body weight appeared to be appropriate, since the same conclusions could be drawn regardless of whether the data was normalised to body weight or liver protein. 
Irrespective of hyperinsulinaemia and hyperglycaemia, total glucose output (glucose-6-phosphatase flux) was not affected, while endogenous glucose production was only modestly inhibited in $o b / o b$ mice. This points to hepatic insulin resistance. Previously reported values of endogenous glucose production in C57Bl/6 mice are almost identical to those reported in this study in lean littermates of $o b / o b$ mice $[16,17]$. Furthermore, endogenous glucose production in C57B1/6 mice could be suppressed almost completely during hyperinsulinaemic clamp at normal or increased glucose concentrations [16, 17] (and unpublished observations, A. Grefhorst et al.). The impaired suppression of endogenous glucose production was mainly due to the blunted response of de novo synthesis of G6P to the combined hyperinsulinaemia and hyperglycaemia in $o b / o b$ mice. This indicates that, in the absence of leptin, insulin appears to be largely ineffective in suppressing hepatic de novo synthesis of G6P by an as yet unknown mechanism.

In the liver of $o b / o b$ mice, the decreased contribution of endogenous glucose production to total glucose output appeared to be compensated by enhanced glucose cycling. Glucose cycling was increased by a factor of $\sim 2.5$ in the liver of $o b / o b$ mice, due to an enhanced flux through glucokinase. A previous study reported a high rate of glucose cycling in hepatocytes isolated from the liver of $o b / o b$ mice fasted for $24 \mathrm{~h}$ [5]. Similarly, in an earlier publication, glucokinase activity was found to remain elevated in the liver of $o b / o b$ mice throughout a 48-h fast [18]. Collectively, these observations indicate that, independent of the duration of fasting, the liver of $o b / o b$ mice maintains a high capacity to phosphorylate glucose.

Besides hepatic insulin resistance, peripheral organs were also found to be insulin resistant in $o b / o b$ mice. Metabolic clearance of plasma glucose was decreased by a factor of $\sim 2$ at blood glucose concentrations that were almost double that in lean mice. This indicates that net glucose uptake by peripheral tissue was similar in $o b / o b$ and lean mice, irrespective of the elevated insulin concentrations in the obese group. Thus, hyperglycaemia in $o b / o b$ mice is due to peripheral insulin resistance. This finding is in agreement with an earlier study using different means to investigate peripheral insulin resistance in $o b / \mathrm{ob}$ mice, which reported that uptake of 2-deoxyglucose was severely inhibited in isolated skeletal muscle of obese mice compared with that in lean mice [19].

As discussed, we observed 'normal' rates of total glucose output and high rates of glucose cycling. In accordance with these observations, "normal' mRNA levels of the gluconeogenic enzymes G6P hydrolase and phosphoenolpyruvate carboxykinase were observed, while mRNA levels of glucokinase and liver-type pyruvate kinase were significantly increased in the liver of obese mice compared to those in liver of lean littermates. Significant increases in mRNA levels of Srebp- 1c and its target genes in lipogenesis, i.e. Fas and Accl, in livers of fasted $o b / o b$ mice have previously been reported $[13,20]$. This indicates an enhanced glycolytic flux into lipogenesis. It should be realised that the glycolytic flux as part of the glucokinase flux cannot be assessed in the isotopic model applied. Recent data indicate that hyperglycaemia could directly induce increased expression of the genes encoding Srebp-1c and pyruvate kinase in an insulin-independent way [21].

In humans with type 2 diabetes, there is evidence for enhanced gluconeogenesis and glycogenolysis after an overnight fast, particularly in patients with severe fasting hyperglycaemia $[1,22,23,24,25,26$, 27]. Although liver was insulin resistant in $o b / o b$ mice, this did not result in enhanced hepatic glucose production. In the present study, only a moderate fasting hyperglycaemia was observed in $o b / o b$ mice at 8 weeks of age. Apparently, in these mice the disease had not yet progressed to a more severe stage with (very) high fasting blood glucose concentrations. Furthermore, in most studies on (often obese) diabetic subjects, the data was normalised to lean body mass instead of body weight, which might have led to seemingly elevated values for gluconeogenic and glycogenolytic fluxes in these individuals compared with those in non-diabetic subjects. Until now, only very few studies have considered the role of glucose cycling in hepatic glucose production. There are indications that hepatic cycling of glucose is elevated in humans with type 2 diabetes [2, 3].

In conclusion, this study demonstrates that in $o b / o b$ mice, de novo synthesis of G6P is diminished while glucose cycling is increased, resulting in an unaffected total glucose output by the liver. However, these observations were made where there was a background of hyperglycaemia and hyperinsulinaemia. This points to a co-existence of hepatic and peripheral insulin resistance, with peripheral insulin resistance as the cause of hyperglycaemia.

Acknowledgements. This work was supported by the Dutch Diabetes Foundation (grant 96.604). R.H.J. Bandsma is supported by the Dutch Organisation for Scientific Research (NWO). We thank T. Boer, P. Modderman and T. Jager for excellent technical assistance.

\section{References}

1. DeFronzo RA, Bonadonna RC, Ferrannini E (1992) Pathogenesis of NIDDM. A balanced overview. Diabetes Care $15: 318-368$

2. Efendic S, Wajngot A, Vranic M (1985) Increased activity of the glucose cycle in the liver: early characteristic of Type 2 diabetes. Proc Natl Acad Sci USA 82:29652969

3. Rooney DP, Neely RDG, Beatty O et al. (1993) Contribution of glucose/glucose-6-phosphate cycle activity to insulin resistance in Type 2 (non-insulin-dependent) diabetes mellitus. Diabetologia 36:106-112 
4. Shull KH, Mayer J (1956) The turnover of liver glycogen in obese hyperglycemic mice. J Biol Chem 218:885896

5. Lahtela JT, Wals PA, Katz J (1990) Glucose metabolism and recycling by hepatocytes of $O B / O B$ and $o b / o b$ mice. Am J Physiol 259:E389-E396

6. Lee WN, Byerley LO, Bergner EA, Edmond J (1991) Mass isotopomer analysis: theoretical and practical considerations. Biol Mass Spectrom 20:451-458

7. Hellerstein MK, Neese RA, Linfoot P, Christiansen M, Turner S, Letscher A (1997) Hepatic gluconeogenic fluxes and glycogen turnover during fasting in humans. A stable isotope study. J Clin Invest 100:1305-1319

8. Van Dijk TH, Van der Sluijs FH, Wiegman $\mathrm{CH}$ et al. (2001) Acute inhibition of hepatic glucose-6-phosphatase does not affect gluconeogenesis but directs gluconeogenic flux toward glycogen in fasted rats. A pharmacological study with the chlorogenic acid derivative S4048. J Biol Chem 276:25727-25735

9. Kuipers F, Havinga R, Bosschieter H, Toorop GP, Hindriks FR, Vonk RJ (1985) Enterohepatic circulation in the rat. Gastroenterology 88:403-411

10. Van Dijk TH, Boer TS, Havinga R, Stellaard F, Kuipers F, Reijngoud DJ (2004) Quantification of hepatic carbohydrate metabolism in conscious mice using serial blood and urine spots. Anal Biochem 322:1-13

11. Lowry OH, Rosebrough NJ, Farr AL, Randall RL (1951) Protein measurement with the Folin phenol reagent. J Biol Chem 193:265-275

12. Rognstad R (1994) Isotopic estimation of the hepatic glucose balance in vivo. J Theor Biol 168:161-173

13. Wiegman CH, Bandsma RHJ, Ouwens M et al. (2003) Hepatic VLDL production in $o b / o b$ mice is not stimulated by massive de novo lipogenesis but is less sensitive to the suppressive effects of insulin. Diabetes 52:1081-1089

14. Landau BR, Wahren J, Chandramouli V, Schumann WC, Ekberg K, Kalhan SC (1996) Contributions of gluconeogenesis to glucose production in the fasted state. J Clin Invest 98:378-385

15. Landau BR, Wahren J, Ekberg K, Previs SF, Yang D, Brunengraber H (1998) Limitations in estimating gluconeogenesis and Cori cycling from mass isotopomer distributions using $\left[\mathrm{U}^{13} \mathrm{C}_{6}\right]$ glucose. Am J Physiol 274:E954-E961

16. Massillon D, Chen W, Hawkins M, Liu R, Barzilai N, Rossetti L (1995) Quantification of hepatic glucose fluxes and pathways of hepatic glycogen synthesis in conscious mice. Am J Physiol 269:E1037-E1043

17. Ren J-M, Marshall BA, Mueckler MM, McCaleb M, Amatruda JM, Shulman G (1995) Overexpression of Glut4 protein in muscle increases basal and insulin-stimulated whole body glucose disposal in conscious mice. J Clin Invest 95:429-432

18. Hron WT, Sobocinski KA, Menahan LA (1984) Enzyme activities of hepatic glucose utilization in the fed and genetically obese mouse at 4-5 months of age. Horm Metab Res 16:S32-S36

19. Cuendet GS, Loten EG, Jeanrenaud B, Renold AE (1976) Decreased basal, non insulin-stimulated glucose uptake and metabolism by skeletal soleus muscle isolated from obesehyperglycemic (ob/ob) mice. J Clin Invest 58:1078-1088

20. Shimomura I, Bashmakov Y, Horton JD (1999) Increased levels of nuclear SREBP-1c associated with fatty livers in two mouse models of diabetes mellitus. J Biol Chem 274:30028-30032

21. Matsuzaka T, Shimano H, Yahagi N et al. (2004) Insulinindependent induction of sterol regulatory element-binding protein-1c expression in the livers of streptozotocin-treated mice. Diabetes 53:560-569

22. Gastaldelli A, Baldi S, Pettiti M et al. (2000) Influence of obesity and Type 2 diabetes on gluconeogenesis and glucose output in humans: a quantitative study. Diabetes 49:1367-1373

23. Magnusson I, Rothman DL, Katz LD, Shulman RG, Shulman GI (1992) Increased rate of gluconeogenesis in type II diabetes mellitus. $\mathrm{A}^{13} \mathrm{C}$ nuclear magnetic resonance study. J Clin Invest 90:1323-1327

24. Boden G, Chen X, Capulong E, Mozzoli M (2001) Effects of free fatty acids on gluconeogenesis and autoregulation of glucose production in Type 2 diabetes. Diabetes 50:810816

25. Tayek JA, Katz J (1996) Glucose production, recycling, and gluconeogenesis in normals and diabetics: a mass isotopomer [U-13C]glucose study. Am J Physiol 270:E709E717

26. Consoli A, Nurjhan N, Capani F, Gerich J (1989) Predominant role of gluconeogenesis in increased hepatic glucose production in NIDDM. Diabetes 38:550-557

27. Consoli A, Nurjhan N (1990) Contribution of gluconeogenesis to overall glucose output in diabetic and non diabetic men. Ann Med 22:191-195 